\title{
Metabolic and Psychological Response to 7-Day Fasting in Obese Patients with and without Metabolic Syndrome
}

\author{
Chenying Li ${ }^{\mathrm{a}, \mathrm{b}}$ Thomas Ostermann ${ }^{\mathrm{c}}$ Monika Hardt ${ }^{\mathrm{d}}$ Rainer Lüdtke \\ Martina Broecker-Preuss ${ }^{f} \quad$ Gustav Dobos $^{d} \quad$ Andreas Michalsen $^{b, g}$ \\ a Department of Traditional Chinese Medicine, First Affiliated Hospital, Sun Yat-Sen University, Guangzhou, China \\ ${ }^{\mathrm{b}}$ Institute of Social Medicine, Epidemiology, and Health Economics, Charité - Universitätsmedizin Berlin, \\ ${ }^{c}$ University of Witten/Herdecke, Center for Integrative Medicine, Herdecke, \\ ${ }^{\mathrm{d}}$ Department of Complementary and Integrative Medicine, Kliniken Essen-Mitte, Faculty of Medicine, University of Duisburg-Essen, \\ ${ }^{\mathrm{e}}$ Karl and Veronica Carstens Foundation, Essen, \\ ${ }^{f}$ Department of Endocrinology and Division of Laboratory Research, University Hospital of Essen, University of Duisburg-Essen, \\ ${ }^{g}$ Department of Internal and Complementary Medicine, Immanuel Hospital Berlin, Germany
}

\section{Keywords}

Adipokines - Caloric restriction · Fasting · Metabolic syndrome Mood

\section{Summary}

Background: Extended modified fasting is a frequently practiced tradition in Europe. It is claimed to improve the cardiometabolic state and physical and psychological well-being by an evolutionary co-developed adaptation response. We aimed to investigate the cardiometabolic and psychological effects of a 7-day fast and differences of these responses between patients with or without metabolic syndrome (MetS). Methods: We investigated 30 female subjects $(49.0 \pm 8.1$ years, BMI $\left.30.4 \pm 6.7 \mathrm{~kg} / \mathrm{m}^{2}\right)$ with $(\mathrm{n}=12)$ and without $(\mathrm{n}=18)$ MetS. All subjects participated in a 7-day fast according to Buchinger with a nutritional energy intake of $300 \mathrm{kcal} / \mathrm{day}$ and stepwise reintroduction of solid food thereafter. Outcomes were assessed baseline and after fasting and included measures of metabolic and glucoregulatory control, adipokines as well as psychological well-being as assessed by Profile of Mood States (POMS) and Hospital Anxiety and Depression Scale (HADS). Results: Mean weight decreased from $85.4 \pm 18.8 \mathrm{~kg}$ to $79.7 \pm$ $18.2 \mathrm{~kg}$ accompanied by systolic/diastolic blood pressure (BP) reduction of $-16.2 \mathrm{~mm} \mathrm{Hg}(95 \% \mathrm{Cl}:-9.1 ;-23.3 \mathrm{~mm} \mathrm{Hg})$ and $-6.0 \mathrm{~mm} \mathrm{Hg}(95 \%$ $\mathrm{Cl}:-1.8 ;-10.3 \mathrm{~mm} \mathrm{Hg}$ ), each $\mathrm{p}<0.001$ and $\mathrm{p}=0.005$. Fasting led to marked decreases of levels of LDL-cholesterol, leptin, and insulin and increases of levels of adiponectin, leptin receptors, and resistin. Fasting-induced mood enhancement was reflected by decreased anxiety, depression, fatigue, and improved vigor. Patients with MetS showed some greater changes in BP, LDL-cholesterol, triglycerides, adiponectin, leptin, and sleep quality. Fasting was well-tolerated. Conclusions: Our results point to marked beneficial responses to 7-day modified fasting and a potential role in the prevention of the MetS. Randomized trials with longer observation periods should test the clinical effectiveness of fasting in metabolic diseases.
Schlüsselwörter

Adipokine - Kalorienrestriktion · Fasten - Metabolisches Syndrom · Gemütszustand

\section{Zusammenfassung}

Hintergrund: Heilfasten in Form des modifizierten Fastens wird in Europa häufig praktiziert und verbessert aufgrund einer evolutiven umweltbedingten Anpassung insbesondere den kardiometabolischen Zustand sowie das physische und psychische Wohlbefinden. In dieser Studie wurde das Ziel verfolgt, die kardiometabolischen und psychischen Effekte 7-tägigen Fastens sowie die genannten Anpassungsunterschiede zwischen Patienten mit und ohne metabolisches Syndrom (MetS) zu untersuchen. Methoden: Untersucht wurden 30 Frauen $(49,0 \pm 8,1 \mathrm{Jah}-$ re, BMI $30,4 \pm 6,7 \mathrm{~kg} / \mathrm{m} 2)$ mit $(n=12)$ und ohne $(n=18)$ MetS. Alle Teilnehmerinnen unterzogen sich einem 7-tägigen Fastenprogramm nach Buchinger, das aus einer Energiezufuhr von $300 \mathrm{kcal} / \mathrm{Tag}$ und einem nachfolgenden schrittweisen Nahrungsaufbau bestand. Die Endpunkterhebungen erfolgten zu Beginn und nach dem Fasten und beinhalteten laborchemische Messungen des kardiometabolischen Profils, endokriner Parameter und Adipokine sowie des psychischen Wohlbefindens, erfasst mittels des "Profile of Mood States" (POMS) und der «Hospital Anxiety and Depression Scale" (HADS). Ergebnisse: Das durchschnittliche Gewicht sank von $85,4 \pm 18,8 \mathrm{~kg}$ auf 79,7 $\pm 18,2 \mathrm{~kg}$, begleitet von einer systolischen/diastolischen Blutdrucksenkung von $-16,2 \mathrm{~mm} \mathrm{Hg}$ (95\% Cl: $-9,1 ;-23,3 \mathrm{~mm} \mathrm{Hg})$ und $-6,0 \mathrm{~mm} \mathrm{Hg}$ (95\% Cl: $-1,8 ;-10,3 \mathrm{~mm}$ $\mathrm{Hg}$ ), jeweils $\mathrm{p}<0,001$ und $\mathrm{p}=0,005$. Das Fasten führte zu einer deutlichen Senkung des LDL-Cholesterin-, Leptin- und Insulins-Spiegels und zu einem Anstieg des Adiponectin-, Leptinrezeptor- und Resistin-Spiegels. Das Fasten führte zu einer Verbesserung des psychischen Befindens, reflektiert durch reduzierte Scores von Angst, Depressivität und Fatigue sowie erhöhte Vitalität. Patienten mit MetS zeigten einige ausgeprägtere fasteninduzierte Veränderungen, insbesondere des Blutdrucks, des LDL-Cholesterins, der Triglyczeride, des Adiponectins, des Leptins und der Schlafqualität. Das Fasten war gut verträglich. Schlussfolgerungen: Die Ergebnisse dieser Erhebung deuten auf relevante gesundheitsfördernde Effekte eines 7-tägigen modifizierten Fastens hin sowie auf die potenzielle Bedeutung des Fastens bei der Prävention des MetS. Randomisierte Studien mit längeren Beobachtungsperioden sind sinnvoll, um die klinische Effektivität von Fasten auf metabolische Krankheiten zu evaluieren.

\section{KARGER \\ Fax +497614520714 \\ Information@Karger.com}

www.karger.com/fok $\begin{array}{ll}\text { (c) 2013 S. Karger GmbH, Freiburg } & \text { Karger } \\ 1661-4119 / 13 / 0206-0413 \$ 38.00 / 0 & \text { Open access }\end{array}$

This is an Open Access article licensed under the terms of the Creative Commons Attribution-NonCommercial 3.0 Unported license (CC BY-NC) (www.karger.com/OA-license), applicable to the online version of the article only. Distribution permitted for non-commercial purposes only.
Andreas Michalsen, $\mathrm{MD}, \mathrm{PhD}$

Zentrum für Naturheilkunde, Immanuel Krankenhaus Berlin

Am kleinen Wannsee 5,14106 Berlin, Germany

a.michalsen@immanuel.de 


\section{Background}

The metabolic syndrome (MetS) is characterized by insulin resistance, glucose intolerance, dyslipidemia, hypertension, and obesity [1]. It affects one-quarter of the American population [2] and is becoming increasingly prevalent in Europe [3]. In Germany the prevalence of MetS is estimated to amount to $40.4 \%$ [4]. Excess weight and weight gain during adult life increases the risk of several diseases including diabetes, cardiovascular disease, stroke, and dementia and can contribute to premature death. Although weight control is beneficial in reducing the incidence and progression of many of these diseases, the problem of poor compliance with weight loss programs is well known. Sustainable and effective energy restriction strategies are thus required. One possible approach might be intermittent fasting with severe calorie restriction (75-90\% of energy needs) on 1 or 2 days per week [5]. Another traditional method is extended modified fasting [6]. In the recent past modified fasting attracted a growing popularity in German public as a self-care method for health and particularly to initiate lifestyle modification [7,8]. Modified fasting may interrupt receptor resistances and modulate favorably the neuroendocrine regulation of metabolism, as has been shown for insulin and natriuretic peptides [9]. Furthermore, fasting may enhance adherence with health promoting lifestyle modification [7].

In a cultural context, periods of deliberate fasting with restriction to intake of solid food have been practiced worldwide, mostly on a traditional or religious background. Within the medical application different types of fasting can be differentiated. Clinically, fasting over 5-28 days with a daily intake of $200-500 \mathrm{kcal}$ by fruits or juice is well established and defines the today mostly used form of modified medical fasting, fasting according to Buchinger. This fasting method is well described and methodological guidelines have been published previously [10]. The clinical effects of therapeutic fasting [10] have been investigated and confirmed by controlled trials in some of the traditionally claimed indications, e.g., rheumatoid arthritis [11, 12]. Some studies have further documented a relevant blood pressure $(\mathrm{BP})$ reducing effect of total fasting [13, 14], and observational data pointed to lasting beneficial effects after 1-2 weeks of modified fasting in obese patients with MetS [15].

The human body exhibits a multitude of adaptive biochemical and physiological responses to extended periods of fasting which likely enabled mankind to survive in periods of food deprivation. Fasting leads to initial stimulation of the hypothalamic pituitary adrenal (HPA) axis as a characteristic physiologic equivalent of a stress reaction [16-18]. Leptin decrease following the initiation of fasting has been identified as strong signal and may play a crucial role in the neuroendocrine signalling in response to fasting [19]. So far, there are no data available comparing directly within one study and one protocol the cardiometabolic and psychological effects of modified fasting in patients with and without MetS. Furthermore, most of the existing studies on fasting had observed patients during a hospital stay or a retreat situation, thus other factors than fasting may have contributed to the effects. Therefore, we aimed to investigate the metabolic and hormonal effects of a 7-day Buchinger fasting within a 2-week nutritional intervention in an outpatient setting while subjects maintained their daily life activities. With a fasting length of 7 days we chose a relative short period of Buchinger fasting. More recently, fasting periods of 5-7 days were more commonly applied.

This reflects the current need for concise interventions with consideration of health economic aspects, while maintaining a minimum time period to induce adaptation responses. We enrolled subjects with MetS and healthy subjects without MetS in order to analyze effects according to the metabolic state. Empirical observation indicates that specifically patients with MetS may frequently experience fasting-induced mood enhancement. Moreover, the previously observed beneficial effects of fasting on receptor resistances suggest that fasting may be specifically useful in MetS.

\section{Methods}

\section{Subjects and Study Design}

The study was planned and conducted as an uncontrolled prospective interventional study. The study period comprised 14 days. Assessments were done at a pre-study screening visit, in the morning of study day 4 (first morning of fasting), and on study day 8 (last day of fasting).

Subjects with MetS and healthy subjects without MetS were searched by means of advertisements placed in local newspapers. A total of 51 individuals responded and 30 were deemed eligible to participate after the screening assessment. As previous studies of our group found predominantly women to be interested in fasting cures, the study was pre-planned with female participants only to ensure the homogeneity of the population. The study was approved by the Ethics Committee of the Medical Faculty of the University Hospital Essen. All participants gave written informed consent to participate in the study. Key inclusion criteria were as follows: age 35-65 years, body mass index (BMI) $20-45 \mathrm{~kg} / \mathrm{m}^{2}$, and willingness to participate in fasting and the study examinations. Exclusion criteria were history of cancer, history of cardiovascular disease or other severe internal disease, history of eating disorder, psychosis, current addiction or pregnancy, current regular intake of medication, weight loss during the previous 3 months of $>3 \mathrm{~kg}$, and inadequate cognitive abilities of cooperation. All enrollment criteria were reviewed in a screening telephone call and confirmed at the first study visit.

For data analyses the 30 patients were further divided into 2 groups, depending on the presence of a MetS. For diagnosis of MetS, patients were required to have 3 or more of the following criteria: 1) abdominal adiposity ( $\geq 88 \mathrm{~cm}) ; 2$ ) low HDL-cholesterol(C) levels ( $\leq 50 \mathrm{mg} / \mathrm{dl}) ; 3$ ) hypertriglyceridemia ( $\geq 150 \mathrm{mg} / \mathrm{dl}) ; 4)$ elevated BP $(\geq 130 / 85 \mathrm{~mm} \mathrm{Hg}) ; 5)$ impaired glucose homeostasis (fasting plasma glucose $\geq 110 \mathrm{mg} / \mathrm{dl}$ ). Of the 30 participants 12 fulfilled the criteria for diagnosis of manifest MetS, the remaining 18 patients had no MetS and were free of severe disease as assessed by clinical examination by the study physician.

\section{Fasting and Diet Protocol}

The 2-week study and dietary intervention period consisted of 2 prefast days with moderate caloric restriction followed by 7 modified fasting days according to Buchinger [10] followed by gradual reintroduction of ordinary food intake over 3 days. 
Table 1. Baseline values and changes in physiological and psychological variables before and after fasting for all patients $(\mathrm{N}=30)$

\begin{tabular}{|c|c|c|c|c|}
\hline & Baseline & Fasting day 8 & Change (95\% CI ) & p-value* \\
\hline Weight, kg & $85.4 \pm 18.8$ & $79.7 \pm 18.2$ & $-5.7(-5.1,-6.2)$ & $<0.001$ \\
\hline BMI, $\mathrm{kg} / \mathrm{m}^{2}$ & $30.4 \pm 6.7$ & $28.3 \pm 6.3$ & $-2.1(-1.6,-2.6)$ & $<0.001$ \\
\hline SBP, $\mathrm{mm} \mathrm{Hg}$ & $130.7 \pm 25.0$ & $114.5 \pm 16.1$ & $-16.2(-9.1,-23.3)$ & $<0.001$ \\
\hline $\mathrm{DBP}, \mathrm{mm} \mathrm{Hg}$ & $83.3 \pm 13.3$ & $77.3 \pm 9.4$ & $-6.0(-1.8,-10.3)$ & 0.005 \\
\hline Total C, mg/dl & $208.4 \pm 38.4$ & $168.9 \pm 27.7$ & $-39.6(-30.0,-49.1)$ & $<0.001$ \\
\hline HDL & $61.0 \pm 17.2$ & $57.1 \pm 14.1$ & $-3.9(-0.7,-7.1)$ & 0.017 \\
\hline LDL & $127.4 \pm 34.7$ & $96.7 \pm 21.6$ & $-30.7(-22.1,-39.3)$ & $<0.001$ \\
\hline LDL/HDL ratio & $2.3 \pm 1.1$ & $1.8 \pm 0.6$ & $-0.5(-0.3,-0.7)$ & $<0.001$ \\
\hline Triglycerides, mg/dl & $117.8 \pm 45.0$ & $106.8 \pm 44.3$ & $-11.1(-23.3,1.1)$ & 0.075 \\
\hline \multicolumn{5}{|l|}{ Cortisol, ng/ml } \\
\hline Morning & $4.1 \pm 4.5$ & $7.2 \pm 4.5$ & $3.1(0.6,5.6)$ & 0.015 \\
\hline Evening & $5.4 \pm 3.5$ & $6.5 \pm 3.3$ & $1.1(0.6,2.8)$ & 0.208 \\
\hline Adiponectin, $\mu \mathrm{g} / \mathrm{ml}$ & $12.4 \pm 6.0$ & $14.9 \pm 5.1$ & $2.5(1.3,3.8)$ & $<0.001$ \\
\hline Leptin, $\mathrm{ng} / \mathrm{ml}$ & $26.9 \pm 20.3$ & $9.7 \pm 15.5$ & $-17.1(-11.7,-22.5)$ & $<0.001$ \\
\hline Receptors & $21.1 \pm 8.2$ & $76.5 \pm 28.2$ & $55.3(44.7,67.5)$ & $<0.001$ \\
\hline Resistin, ng/ml & $4.6 \pm 1.6$ & $6.9 \pm 2.4$ & $2.3(1.7,2.9)$ & $<0.001$ \\
\hline Insulin, $\mu \mathrm{U} / \mathrm{ml}$ & $14.0 \pm 19.0$ & $3.2 \pm 4.0$ & $-10.8(-4.7,-16.8)$ & 0.001 \\
\hline Hs-CRP, mg/dl & $0.2 \pm 0.2$ & $0.5 \pm 0.3$ & $0.3(0.1,0.4)$ & $<0.001$ \\
\hline \multicolumn{5}{|l|}{ Sleep score } \\
\hline Fatigue & $4.8 \pm 2.2$ & $2.9 \pm 2.1$ & $-1.9(-1.2,-3.5)$ & $<0.001$ \\
\hline Quality & $4.5 \pm 2.0$ & $6.2 \pm 2.8$ & $1.7(0.2,3.3)$ & 0.03 \\
\hline \multicolumn{5}{|l|}{ POMS } \\
\hline Depression & $1.1 \pm 1.2$ & $0.4 \pm 0.7$ & $-0.7(-0.3,-1.2)$ & 0.001 \\
\hline Fatigue & $2.1 \pm 1.5$ & $1.0 \pm 1.2$ & $-1.1(-0.5,-1.7)$ & 0.001 \\
\hline Vigor & $3.0 \pm 1.1$ & $3.4 \pm 1.2$ & $0.4(-0.2,1.0)$ & 0.168 \\
\hline Anger/hostility & $1.1 \pm 1.0$ & $0.2 \pm 0.5$ & $-0.9(-0.5,-1.2)$ & $<0.001$ \\
\hline \multicolumn{5}{|l|}{ HADS } \\
\hline Anxiety & $7.2 \pm 4.2$ & $4.9 \pm 3.2$ & $-2.3(-1.1,-3.6)$ & $<0.001$ \\
\hline Depression & $5.3 \pm 4.4$ & $3.3 \pm 3.0$ & $-2.0(-3.4,0.5)$ & 0.10 \\
\hline
\end{tabular}

During the initial 2 pre-fast days subjects received a 3,350 kJ (800 kcal) / day, low-calorie, and low-salt diet with intake of pure cooked rice and vegetables only. The fasting period started on the evening of study day 3 and lasted to the afternoon at study day 11. During the fasting period subjects received unrestricted amounts of herbal tea (no black or green tea), $200 \mathrm{cl}$ fruit juice, and small standardized quantities of light vegetable soup with a maximum total daily energy intake of $1,255 \mathrm{~kJ}$ (300 kcal). Fasting started with oral ingestion of a laxative salt ( $30-40 \mathrm{~g}$ sodium sulfate). While preparing to fast, it is common practice to achieve emptiness of the bowels by the most effective way. Bowel motility thus can be reduced once fasting has started, avoiding retarded and therefore unfavorable digestion of bowel contents present at the beginning. Patients were strongly advised to drink 2-31 of fluids daily. The fasting period was followed by 3 low-calorie diet days with stepwise reintroduction of solid food. A mild calorie-restricted diet with intake of $1.800 \mathrm{kcal} /$ day was reached again thereafter. Participants were strictly advised not to consume caffeine containing or alcoholic beverages.

Each day during the study period the participants had a group meeting within the hospital where the diet lunch and some fasting beverages were taken together.

Throughout the study, the subjects continued their usual daily and professional activities. No other therapies were delivered. Weekends were on study days $2 / 3$ and $9 / 10$. Compliance with the fasting procedure was controlled daily by measurements of urine $\mathrm{pH}$ and at the end of fasting period by a personal interview.

\section{Measurements}

Subjects height and body weight were measured following a standardized protocol while patients wore light clothing and no shoes after an overnight fast. BMI was calculated as weight $(\mathrm{kg}) /$ height $(\mathrm{m})^{2}$. Subjects' waist was measured with a soft tape midway between the lowest rib and the iliac crest. Anthropometrical and clinical data were collected by trained study personnel. Seated BP and pulse rate were measured after 5 min rest with a calibrated sphygmomanometer at the non-dominant arm by trained nurses.

\section{Laboratory}

Blood samples were drawn in the morning of study day 4 and study day 11. Assays for blood lipids and glucose were performed with standard methods. Serum concentrations of insulin and high-sensitivity(hs)-CRP were measured by immunonephelometric methods (BN-II-nephelometer, Siemens, Fernwald, Germany). Plasma adiponectin, leptin, and resistin concentrations were quantified using a high sensitivity enzyme-linked immunosorbent assay (ELISA). Salivary cortisol was measured by radioimmunoassay. Leptin receptor concentration (LepR-e) was measured with standardized and established methods of the laboratory. All analyses were performed at the Central Laboratory of the University Hospital Essen. Adverse events were monitored by diary and at the last study visit by interview. 
Table 2. Metabolic parameters and risk factors, quality of sleep and psychological well-being: Change before and after fasting in patients with and without MetS. Mean values \pm SD, mean change ( $95 \%$ CI) before and after fasting with respective P-values

\begin{tabular}{|c|c|c|c|c|c|c|c|c|}
\hline \multirow[t]{2}{*}{ Variable } & \multicolumn{4}{|l|}{ MetS } & \multicolumn{4}{|l|}{ No MetS } \\
\hline & baseline & day 8 & change $(95 \% \mathrm{CI})$ & p-value* & baseline & day 8 & change $(95 \% \mathrm{CI})$ & p-value* \\
\hline Weight, kg & $100.1 \pm 17.0$ & $94.7 \pm 17.1$ & $-5.6(-4.8,-6.5)$ & $<0.001$ & $77.0 \pm 13.1$ & $71.7 \pm 11.7$ & $-5.3(-4.8,-5.9)$ & $<0.001$ \\
\hline $\mathrm{BMI}, \mathrm{kg} / \mathrm{m}^{2}$ & $35.5 \pm 6.4$ & $33.3 \pm 6.1$ & $-2.2(-1.4,-3.0)$ & $<0.001$ & $27.0 \pm 4.4$ & $25.0 \pm 4.0$ & $-2.0(-1.4,-2.7)$ & $<0.001$ \\
\hline SBP, mm Hg & $146.3 \pm 29.8$ & $126.4 \pm 16.4$ & $-20.0(-5.3,-34.6)$ & 0.008 & $120.3 \pm 14.4$ & $106.6 \pm 10.2$ & $-13.7(-6.8,-20.5)$ & $<0.001$ \\
\hline DBP, mm Hg & $87.9 \pm 17.4$ & $81.2 \pm 11.3$ & $-6.7(-16.0,2.5)$ & 0.151 & $80.3 \pm 9.0$ & $74.7 \pm 7.0$ & $-5.6(-9.4,1.8)$ & 0.004 \\
\hline Total C, mg/dl & $216.0 \pm 48.5$ & $168.6 \pm 36.9$ & $-47.4(-30.7,-64.2)$ & $<0.001$ & $203.4 \pm 30.5$ & $169.0 \pm 20.7$ & $-34.4(-23.3,-45.4)$ & $<0.001$ \\
\hline HDL & $48.3 \pm 13.8$ & $49.0 \pm 13.7$ & $0.7(-5.2,3.8)$ & 0.760 & $69.4 \pm 13.9$ & $62.4 \pm 11.9$ & $-7.0(-3.1,-10.9)$ & $<0.001$ \\
\hline LDL & $142.3 \pm 43.7$ & $100.1 \pm 27.6$ & $-42.1(-26.2,-58.0)$ & $<0.001$ & $117.6 \pm 23.7$ & $94.4 \pm 17.0$ & $-23.2(-14.9,-31.4)$ & $<0.001$ \\
\hline LDL/HDL ratio & $3.1 \pm 1.3$ & $2.1 \pm 0.7$ & $-1.0(-0.6,-1.4)$ & $<0.001$ & $1.8 \pm 0.5$ & $1.6 \pm 0.4$ & $-0.2(-0.3,0.0)$ & 0.017 \\
\hline Triglycerides, mg/dl & $155.3 \pm 43.7$ & $136.1 \pm 51.1$ & $-19.2(-5.2,-43.6)$ & 0.123 & $92.9 \pm 23.8$ & $87.2 \pm 25.4$ & $-5.7(-17.9,6.6)$ & 0.364 \\
\hline \multicolumn{9}{|l|}{ Cortisol, ng/ml } \\
\hline Morning & $3.4 \pm 2.7$ & $7.4 \pm 5.3$ & $4.0(0.2,7.9)$ & 0.038 & $4.6 \pm 5.5$ & $7.0 \pm 4.1$ & $2.4(-5.7,0.9)$ & 0.150 \\
\hline Evening & $5.9 \pm 3.1$ & $6.9 \pm 3.2$ & $1.0(-3.5,1.5)$ & 0.433 & $5.1 \pm 3.7$ & $6.3 \pm 3.3$ & $1.2(-3.6,1.2)$ & 0.331 \\
\hline Resistin, $\mathrm{ng} / \mathrm{ml}$ & $4.8 \pm 1.8$ & $6.9 \pm 2.0$ & $2.1(1.4,2.8)$ & $<0.001$ & $4.4 \pm 1.4$ & $6.8 \pm 2.7$ & $2.4(1.6,3.2)$ & 0.038 \\
\hline Hs-CRP, mg/dl & $0.3 \pm 0.3$ & $0.5 \pm 0.3$ & $0.2(-0.4,0.0)$ & 0.114 & $0.2 \pm 0.2$ & $0.5 \pm 0.3$ & $0.3(0.1,0.5)$ & 0.220 \\
\hline \multicolumn{9}{|l|}{ Sleep score } \\
\hline Fatigue & $5.1 \pm 2.3$ & $2.9 \pm 2.8$ & $-2.3(-0.1,-4.2)$ & 0.038 & $4.6 \pm 2.1$ & $2.9 \pm 1.6$ & $-1.7(-0.5,-2.9)$ & 0.004 \\
\hline Quality & $3.6 \pm 1.6$ & $5.8 \pm 3.5$ & $2.2(-4.5,0.0)$ & 0.052 & $5.1 \pm 1.9$ & $6.5 \pm 2.2$ & $1.4(-2.7,0.1)$ & 0.065 \\
\hline \multicolumn{9}{|l|}{ POMS } \\
\hline Depression & $1.2 \pm 1.4$ & $0.5 \pm 0.9$ & $-0.7(-0.2,1.6)$ & 0.122 & $1.1 \pm 1.1$ & $0.3 \pm 0.6$ & $-0.8(-0.4,-1.2)$ & $<0.001$ \\
\hline Fatigue & $2.1 \pm 1.7$ & $1.1 \pm 1.4$ & $-1.0(-0.3,2.2)$ & 0.127 & $2.2 \pm 1.4$ & $1.0 \pm 1.1$ & $-1.2(-0.5,-1.8)$ & $<0.001$ \\
\hline Vigor & $3.1 \pm 1.3$ & $3.2 \pm 1.5$ & $0.1(-1.2,1.0)$ & 0.873 & $3.0 \pm 1.1$ & $3.6 \pm 1.1$ & $0.6(-1.2,0.0)$ & 0.040 \\
\hline Anger/hostility & $1.1 \pm 1.1$ & $0.3 \pm 0.6$ & $-0.8(0.1,1.4)$ & 0.024 & $1.1 \pm 0.9$ & $0.1 \pm 0.3$ & $-1.0(-0.6,-1.3)$ & $<0.001$ \\
\hline \multicolumn{9}{|l|}{ HADS } \\
\hline Anxiety & $7.5 \pm 4.0$ & $5.1 \pm 3.6$ & $-2.4(-0.3,-4.6)$ & 0.027 & $7.1 \pm 4.4$ & $4.8 \pm 3.0$ & $-2.3(-0.8,-3.8)$ & 0.003 \\
\hline Depression & $5.1 \pm 5.0$ & $3.6 \pm 3.6$ & $-1.5(-1.8,4.7)$ & 0.373 & $5.4 \pm 4.1$ & $3.1 \pm 2.6$ & $-2.3(-1.0,-3.6)$ & 0.001 \\
\hline
\end{tabular}

$\mathrm{BMI}=$ body mass index; $\mathrm{SBP}=$ systolic blood pressure; $\mathrm{DBP}=$ diastolic blood pressure $\mathrm{C}=$ cholesterol; hs $=$ high sensitivity;

POMS $=$ Profile of Mood States; HADS = Hospital Anxiety and Depression Scale.

* Wilcoxon test $P$-values for within-group difference of change, unadjusted; $\mathrm{CI}=$ confidence interval.

\section{Psychological Outcomes}

Psychological outcomes were assessed by 2 validated self-report measures: 1) The German version of the Profile of Mood States (POMS) [20], which is a 34-item instrument that measures 4 domains of mood disturbance including vigor, fatigue, depression, anxiety, and anger; 2) The German version of the Hospital Anxiety and Depression Scale (HADS) [21], a validated standard measure for anxiety and depression which uses a 14-item scale with 7 of the items related to anxiety and 7 related to depression. Quality of sleep was assessed by $100 \mathrm{~mm}$ visual analogue scales (VAS) for self-rated global quality of sleep and day time sleepiness.

\section{Statistical Analyses}

If not indicated otherwise, results were expressed as means \pm standard deviation (SD). Changes of values before and after fasting were calculated by analysis of covariance models (ANCOVA). Missing values were replaced by multiple imputations. A p-value $<0.05$ was considered as statistically significant. As this was an exploratory study we did not perform adjustments for multiple testing. All statistical computations were performed with the statistical software SAS version 8.2.

\section{Results}

A total of 30 subjects were enrolled in the study, with 28 completing the entire fasting period. 1 participant dropped out because of headache attributed to coffee withdrawal. 1 further participant stopped fasting due to gastric pain after the $3 \mathrm{rd}$ day. Of the 30 participants 12 fulfilled the criteria for diagnosis of MetS. Subjects' age ranged from 40 to 73 years with a mean age of $49.0 \pm 8.1$ years and patients with MetS being slightly older $(53.6 \pm 6.7$ vs. $45.9 \pm 7.4$ years $)$. Baseline characteristics of all subjects and the 2 groups according to metabolic state are given in table 1 . Subjects with MetS demonstrated typical clinical differences compared to subjects without MetS, however, subjects without MetS had higher blood insulin and salivary cortisol levels, yet differences were not statistically significant.

\section{Fasting-Induced Changes in the Whole Study Population}

During fasting mean weight of all patients decreased from $85.4 \pm 18.8$ to $79.7 \pm 18.2 \mathrm{~kg}$. Fasting was accompanied by a pronounced decrease in systolic, respectively diastolic BP of 
Fig. 1. Blood concentrations of insulin, adiponectin, leptin, and leptin receptors before and after fasting in subgroups with or without MetS (mean and SD). $* \mathrm{p}<0.05$; ** $\mathrm{p}<0.01 ; * * * \mathrm{p}<0.001$ Mean changes were for MetS patients: adiponectin: $3.5 \mu \mathrm{g} / \mathrm{ml}$ (95\% CI: $2.1 ; 4.9 \mu \mathrm{g}$ ) $\mathrm{ml})$; insulin: $-8.1 \mu \mathrm{U} /$ ml (95\% CI: -1.4 ;

$-14.6 \mu \mathrm{U} / \mathrm{ml})$; leptin: $-19.9 \mathrm{ng} / \mathrm{ml}$ (95\% CI: $-10.1 ;-29.7 \mathrm{ng} / \mathrm{ml})$; leptin receptors: 44.7 ng/ml (95\% CI: 32.1;

$57.1 \mathrm{ng} / \mathrm{ml})$. For patients without MetS as: adiponectin: $1.9 \mu \mathrm{g} / \mathrm{ml}$ (95\% CI: $3.8 ; 0.0 \mu \mathrm{g} /$ $\mathrm{ml}$ ); insulin: $-15.3 \mu \mathrm{U} /$ $\mathrm{ml}$ (95\% CI: -8.9 ; $-21.6 \mu \mathrm{U} / \mathrm{ml})$; leptin: $-15.3 \mathrm{ng} / \mathrm{ml}(95 \% \mathrm{CI}$ : $-8.9 ;-21.6 \mathrm{ng} / \mathrm{ml})$; leptin receptors: $\mu 58.6 \mathrm{ng}$, $\mathrm{ml}(48.2 ;-71.0)$.
A

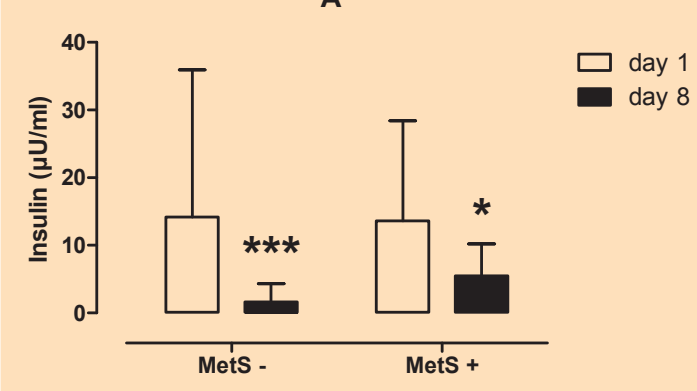

C

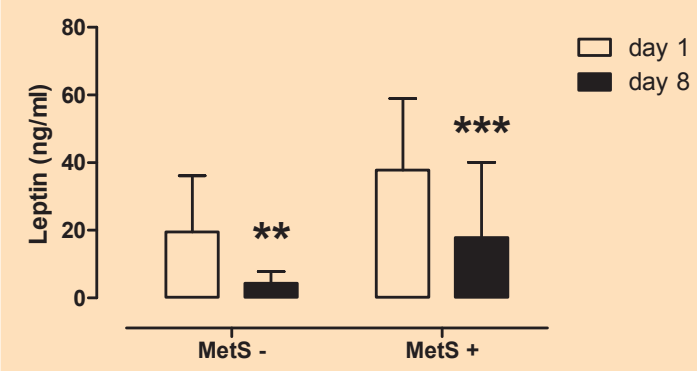

B

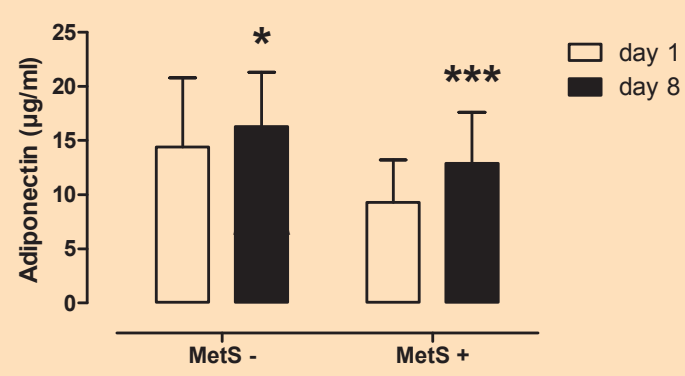

D

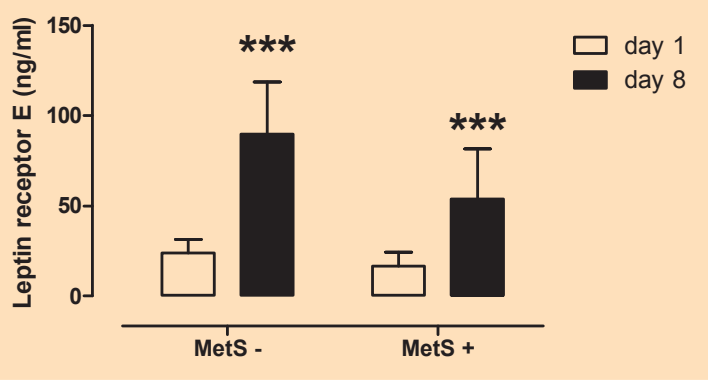

$-16.2 \mathrm{~mm} \mathrm{Hg}$ (95\% CI: $-9.1 ;-23.3 \mathrm{~mm} \mathrm{Hg}$ ) and $-6.0 \mathrm{~mm} \mathrm{Hg}$ (95\% CI: $-1.8 ;-10.3 \mathrm{~mm} \mathrm{Hg}$ ). Blood lipids showed significant decreases in LDL-C, HDL-C, and LDL/HDL ratio. We observed a significant increase of morning salivary cortisol through fasting period, while hs-CRP slightly but significantly increased. Fasting led to a marked drop of insulin and leptin levels with a concomitant pronounced increase in leptin receptors, adiponectin, and resistin (table 1).

The psychological assessments by the POMS documented a fasting-induced mood enhancement which was most pronounced and statistically significant for depression, fatigue, and anger/hostility. Both anxiety and depression as assessed by HADS revealed significant fasting-induced improvements. Concomitantly, quality of sleep increased and day time fatigue related to sleep decreased (table 1).

\section{Fasting-Induced Changes in Subjects with or without MetS}

The presence of MetS had some distinct influence on the fasting-induced changes of metabolic and endocrine outcomes (table 2, fig. 1). Mean systolic BP decreased by $-20.0 \mathrm{~mm} \mathrm{Hg}$ (95\% CI:-5.3;-34.6 mm Hg) in patients with MetS group compared to $-13.7 \mathrm{~mm} \mathrm{Hg}$ (95\% CI:-6.8; $-20.5 \mathrm{~mm} \mathrm{Hg}$ ) in patients without MetS. Mean diastolic BP decreased by $-6.7 \mathrm{~mm} \mathrm{Hg}$ (95\% CI:-16.0,2.5 $\mathrm{mm} \mathrm{Hg}$ ) in patients with MetS compared to $-5.6 \mathrm{~mm} \mathrm{Hg}$ (95\% CI: $-9.4,1.8 \mathrm{~mm} \mathrm{Hg}$ ) in patients without
MetS. LDL-C decrease was slightly pronounced in subjects with MetS who also showed no decrease of HDL-C decrease. Patients with MetS had lower levels of adiponectin and higher levels of leptin at baseline with more pronounced fastinginduced changes. At the end of fasting patients with MetS had reached baseline levels of the MetS without patients. Of note, leptin receptor concentrations increased markedly in both groups. Fasting-induced mood enhancement was observed in both subjects with or without MetS, however with a tendency to greater mood enhancement in subjects without MetS.

\section{Discussion}

This prospective study investigated for the first time the cardiometabolic, endocrine, and psychological effects of a 7-day modified fasting in a sample of middle-aged female outpatients with a $40 \%$ proportion of MetS. Fasting caused an average of $5.5 \%$ weight loss and led to pronounced beneficial effects on glucoregulatory control and the cardiometabolic and endocrine profile, e.g., the leptin-to-adiponectin ratio, which has been linked to insulin sensitivity [22]. Fasting was not associated with relevant hunger or adverse effects and had a significant mood enhancing as well as an antidepressant and anxiety relieving effect. Patients with MetS showed some 
greater changes in BP, LDL-C, triglycerides, adiponectin, leptin, sleep fatigue score, and sleep quality. Our findings indicate that the response of the human body to a 7-day period of fasting can be regarded as a pronounced beneficial and health promoting adaptation process. This adaptation response is not restricted to metabolically diseased subjects.

In a recent trial, caloric restriction with an energy intake of $400 \mathrm{kcal} /$ day quickly improved glucose control [23]. 1 observational and 1 experimental study from established clinical fasting centers in Germany also reported beneficial effects on metabolic and cardiovascular risk factors by fasting according to Buchinger [24, 25]. Some studies have further documented a relevant BP reducing effect of total fasting (water fasting) $[13,14]$. Epidemiological studies further showed that routine periodic fasting with shorter fasting periods of 1-2 days, as practiced by specific religious groups, is associated with a lower risk of coronary artery disease in patients undergoing coronary angiography [26].

Studies on type 2 diabetes patients on a very-low-calorie diet (VLCD) found that after 12 weeks leptin levels decreased while adiponectin levels increased significantly. Similarly, VLCD in obese females induced weight reduction, which was associated with BP decrease and some improvement of metabolic parameters and leptin depletion by $30 \%$ [27, 28], however not to the same extent as in our study. Compared to the results of previous research 2 findings of our study seem important. First, we found marked and clinically relevant changes of important cardiometabolic and hormonal parameters. Second, these pronounced changes were already present after a 7-day fasting period while the traditional approach of Buchinger fasting usually favors longer fasting periods for achieving greater treatment effects.

The mechanisms behind the clinical effects of fasting are not fully understood. Clearly, longer periods of fasting represent a strong physiological stimulus and induce pronounced hormonal changes, e.g., stimulation of the HPA pointing to a mild stress reaction. The hypothalamus is critically involved in the regulation of feeding and fasting. Previous research has shown that glucose ingestion inhibits hypothalamic neuronal activity [29]. A transcription factor has been described which acts as metabolic sensor in neurons of the lateral hypothalamic area to integrate metabolic signals, adaptive behavior, and physiological responses [30]. Functional magnetic resonance imaging studies in diabetic patients undergoing a 4-day VLCD found a normalization of the hypothalamic responsiveness to glucose ingestion after the caloric restriction period [29].

The early hypopituitary adrenergic activation is followed by decreased adrenergic levels after some days. In a prospective study with obese subjects a fast over 16 days led to substantial weight loss paralleled by decreased basal and exerciseinduced serum concentrations of noradrenaline, adrenaline, and dopamine [31]. Moreover, fasting is associated with increases in concentrations of growth hormone and glucagon and leads to pronounced initial natriuresis and diuresis [32].
Studies on VLCD demonstrated an increased BP lowering effect of natriuretic peptides after a 4-day diet period, which might point to effects of fasting receptor sensitivity [33]. Extending these findings, we could show that a 7-day fast largely increases the concentration of soluble leptin receptors. It has previously shown that leptin may play a crucial role in the orchestration of endocrine and metabolic effects of fasting [34, 35]. The cytokines and hormones derived from adipose tissue are referred to as adipokines. Leptin levels in the blood are dependent on the volume of adipose tissue, and caloric restriction significantly inhibits the expression of leptin mRNA [36]. Adiponectin is reduced in patients with obesity and type 2 diabetes and it has been shown experimentally that caloric restriction can increase plasma adiponectin levels [37]. In a randomized trial over 6 months Harvie et al. [38] compared the effect of continuous and intermittent caloric restriction on metabolic disease risk markers in younger overweight women. Decreases in circulating insulin and increases in adiponectin over 1-6 months were less pronounced than in our fasting period, however we do not know the long-term impact of our fasting intervention on insulin and adiponectin.

Surprisingly, fasting led to mild but significant increase in hs-CRP. Inflammatory biomarkers are frequently increased in obese subjects and weight loss through long-term caloric restriction reduces these biomarkers in women [39]. Reduction of inflammatory markers has been described in experimental studies [40]. To the contrary, shorter periods of fasting may lead to a mild stress or hormetic reaction [41] which is associated with increased circulating levels of catecholamines and thereby possibly leading to an acute phase response. Hormetic effects are characterized as an overcompensation of low dose stimulation and stress and are related to human health.

The mood enhancing effect of fasting has been described in earlier studies $[16,18]$. Several mechanisms have been suggested, among them increased central serotonin availability, endorphin release, an increase in central catecholamines, and a modified sleep architecture. Furthermore, insulin and leptin signaling may impact on other central signaling pathways, such as the GABAergic and the dopaminergic system [42]. In an evolutionary context, mood enhancement after several days of food deprivation seems to be an important beneficial psychological adaptation in the search for food and the chance for survival.

Fasting and VLCD have been criticized for resulting in weight cycling due to decrease basal energy consumption and thereby promoting weight gain when re-feeding [43]. In contrast, empirical and observational data [44] indicate that fasting may enhance lifestyle modification with longer-lasting improved behavioral nutritional habits. Accordingly, data from clinical centers that are specialized in fasting therapy could not confirm increased weight gain after fasting [10,15].

Several limitations apply to our study. First, as this was an uncontrolled study we do not know the nonspecific effect of the intervention which may be due to the observation, atten- 
tion, and the social effects through the group meetings. Furthermore, we tried to control compliance by interviews and by urine $\mathrm{pH}$ measurements, which, however, are not reliable in assessing fasting-induced acidosis. Yet, documented continuous weight loss in all our patients seems to support objectively the notion of good compliance of our study participants, as also confirmed in the interviews.

The conduction of randomized controlled trials (RCT) with a fasting intervention is difficult and faces logistical and motivational challenges. However, our results imply that such a RCT is warranted and should compare the long-term effects of extended fasting with other forms of caloric restriction, as alternate day fasting or continuous $20-40 \%$ energy restriction.

\section{Conclusions}

Our results point to marked beneficial cardiometabolic and psychological responses to 7-day modified fasting with some distinct effects in patients with or without MetS. Pronounced adaptation responses on regulating hormones and its receptors indicate a potential role in the prevention of metabolic disease. Randomized trials with longer observation periods should test the clinical effectiveness of fasting in metabolic diseases.

\section{Disclosure Statement}

The study was funded by a grant from the Karl and Veronica Carstens Foundation, Essen, Germany. All authors have no competing interest.

\section{References}

1 Meshkani R, Adeli K: Hepatic insulin resistance, metabolic syndrome and cardiovascular disease. Clin Biochem 2009;42:1331-1346.

2 Ford ES, Giles WH, Dietz WH: Prevalence of the metabolic syndrome among US adults: findings from the Third national Health and Nutrition Examination Survey. JAMA 2002;287:356-359.

$>3$ Redon J, Cifkova R, Laurent S, Nilsson P, Narkiewicz K, Erdine S, Mancia G; Scientific Council of the European Society of Hypertension: The metabolic syndrome in hypertension: European Society of Hypertension position statement. J Hypertens 2008;26:1891-1900.

4 Lafortuna CL, Adorni F, Agosti F, De Col A, Sievert K, Siegfried W, Sartorio A: Prevalence of the metabolic syndrome among extremely obese adolescents in Italy and Germany. Diabetes Res Clin Pract 2010;88:14-21.

5 Mattson MP, Wan R: Beneficial effects of intermittent fasting and caloric restriction on the cardiovascular and cerebrovascular systems. J Nutr Biochem 2005;16:129-137.

6 Michalsen A: Prolonged fasting as a method of mood enhancement in chronic pain syndromes: a review of clinical evidence and mechanisms. Curr Pain Headache Rep 2010;14:80-87.

7 Michalsen A, Hoffmann B, Moebus S, Backer M, Langhorst J, Dobos GJ: Incorporation of fasting therapy in an integrative medicine ward: evaluation of outcome, safety, and effects on lifestyle adherence in a large prospective cohort study. J Altern Complement Med 2005;11:601-607.

$\checkmark$ Hartel U,Volger E: Inanspruchnahme und Akzep$\operatorname{tanz}$ klassischer Naturheilverfahren und alternativer Heilmethoden in Deutschland - Ergebnisse einer repräsentativen Bevölkerungsstudie. Forsch Komplementarmed Klass Naturheilkd 2004;11: 327-334.

9 Dessi-Fulgheri P, Sarzani R, Serenelli M, Tamburrini P, Spagnolo D, Giantomassi L, Espinosa E, Rappelli A: Low calorie diet enhances renal, hemodynamic, and humoral effects of exogenous atrial natriuretic peptide in obese hypertensives. Hypertension 1999;33:658-662.

10 Wilhelmi de Toledo F, Gaisbauer M, Hölz G, Kronsteiner W, Kuhn C, Lischka E, Lischka N, Lützner H, May W, Melchart D, Michalsen A, Müller H, Peper E, Resch K-L, Ritzmann-Widderich M, Wessel A, Wichert H, Stange R: Leitlinien zur Fastentherapie. Forsch Komplementärmed Klass Naturheilkd 2002;9:189-198.

11 Müller H, Wilhelmi de Toledo F, Resch KL: Fasting followed by vegetarian diet in patients with rheumatoid arthritis: a systematic review. Scand J Rheumatol 2001;30:1-10.

12 Kjeldsen-Kragh J, Haugen M, Borchgrevink CF, Laerum E, Eek M, Mowinkel P, Hovi K, Forre O: Controlled trial of fasting and one-year vegetarian diet in rheumatoid arthritis. Lancet 1991;338:899902.

13 Müller H, Wilhelmi de Toledo F, Schuck P, Resch KL: Blutdrucksenkung durch Fasten bei Adipösen und nichtadipösen Hypertonikern. Perfusion 2001; 14:108-112.

14 Goldhamer AC, Lisle DJ, Sultana P, Anderson SV, Parpia B, Hughes B, Campbell TC: Medically supervised water-only fasting in the treatment of borderline hypertension. J Altern Complement Med 2002;8:643-650.

15 Schubmann R: Therapeutisches Fasten bei Adipositas und metabolischem Syndrom. Z Komplementärmed 2009;1:14-17.

16 Schwartz MW, Seeley RJ: Seminars in medicine of the Beth Israel Deaconess Medical Center. Neuroendocrine responses to starvation and weight loss. N Engl J Med 1997;336:1802-1811.

17 Palmblad J, Levi L, Burger A, Melander A, Westgren U, von Schenck H, Skude G: Effects of total energy withdrawal (fasting) on the levels of growth hormone, thyrotropin, cortisol, adrenaline, noradrenaline, T4, T3 and rT3 in healthy males. Acta Med Scand 1977;201:15-22.

18 Michalsen A, Schneider S, Rodenbeck A, Ludtke R, Huether G, Dobos GJ: The short-term effects of fasting on the neuroendocrine system in patients with chronic pain syndromes. Nutr Neurosci 2003; 6:11-18.

19 Ahima RS, Lazar MA: Adipokines and the peripheral and neural control of energy balance. Mol Endocrinol 2008;22:1023-1031.
20 Albani C, Blaser G, Geyer M, Schmutzer G, Brahler E, Bailer H, Grulke N: The German short version of 'Profile of Mood States' (POMS): psychometric evaluation in a representative sample (in German). Psychother Psychosom Med Psychol 2005;55:324-330.

21 Barth J, Martin CR: Factor structure of the Hospital Anxiety and Depression Scale (HADS) in German coronary heart disease patients. Health Qual Life Outcomes 2005;3:15.

22 Finucane FM, Luan J, Wareham NJ, Sharp SJ, O'Rahilly S, Balkau B, Flyvbjerg A, Walker M, Hojlund K, Nolan JJ; European Group for the Study of Insulin Resistance: Relationship between Insulin Sensivity and Cardiovascular Disease Risk Study Group, Savage DB: Correlation of the leptin: adiponectin ratio with measures of insulin resistance in non-diabetic individuals. Diabetologia 2009;52:2345-2349.

23 Malandrucco I, Pasqualetti P, Giordani I, Manfellotto D, De Marco F, Alegiani F, Sidoti AM, Picconi F, Di Flaviani A, Frajese G, Bonadonna RC, Frontoni S: Very-low-calorie diet: a quick therapeutic tool to improve beta cell function in morbidly obese patients with type 2 diabetes. Am J Clin Nutr 2012;95:609-613.

24 Lützner H, Wilhelmi de Toledo F: Fasten/Fastentherapie. Physiologie des Fastens; in Bühring M, Kemper FH, Mathiessen PF (Hrsg): Naturheilverfahren und unkonventionelle medizinische Richtungen. Berlin, Springer, Loseblatt-System, 1998, pp 1-26.

25 Steiniger J, Schneider A, Bergmann S, Boschmann M, Janietz K: Effects of fasting and endurance training on energy metabolism and physical fitness in obese patients (in German). Forsch Komplementmed 2009;16:383-390.

26 Horne BD, May HT, Anderson JL, Kfoury AG, Bailey BM, McClure BS, Renlund DG, Lappe DL, Carlquist JF, Fisher PW, Pearson RR, Bair TL, Adams TD, Muhlestein JB: Usefulness of routine periodic fasting to lower risk of coronary artery disease in patients undergoing coronary angiography. Am J Cardiol 2008;102:814-819. 
27 Oberhauser F, Schulte DM, Faust M, Gudelhofer H, Hahn M, Muller N, Neumann K, Krone W, Laudes M: Weight loss due to a very low calorie diet differentially affects insulin sensitivity and interleukin-6 serum levels in nondiabetic obese human subjects. Horm Metab Res 2012;44:465-470.

28 Morel O, Luca F, Grunebaum L, Jesel L, Meyer N, Desprez D, Robert S, Dignat-George F, Toti F, Simon C, Goichot B: Short-term very low-calorie diet in obese females improves the haemostatic balance through the reduction of leptin levels, pai1 concentrations and a diminished release of platelet and leukocyte-derived microparticles. Int J Obes 2011;35:1479-1486.

29 Teeuwisse WM, Widya RL, Paulides M, Lamb HJ, Smit JW, de Roos A, van Buchem MA, Pijl H, van der Grond J: Short-term caloric restriction normalizes hypothalamic neuronal responsiveness to glucose ingestion in patients with type 2 diabetes. Diabetes 2012;61:3255-3259.

-30 Silva JP, von Meyenn F, Howell J, Thorens B, Wolfrum C, Stoffel M: Regulation of adaptive behaviour during fasting by hypothalamic Foxa2. Nature 2009;462:646-650.

- 31 Gohler L, Hahnemann T, Michael N, Oehme P, Steglich HD, Conradi E, Grune T, Siems WG: Reduction of plasma catecholamines in humans during clinically controlled severe underfeeding. Prev Med 2000;30:95-102.

-32 Spark RF, Arky RA, Boulter PR, Saudek CD O'Brian JT: Renin, aldosterone and glucagon in the natriuresis of fasting. New Engl J Med 1975; 292:1335-1340.
$33 \mathrm{Maoz}$ E, Shamiss A, Peleg E, Salzberg M, Rosenthal T: The role of atrial natriuretic peptide in natriuresis of fasting. J Hypertens 1992;10:10411044.

34 Ahima RS, Prabakaran D, Mantzoros C, Qu D, Lowell B, Maratos-Flier E, Flier JS: Role of leptin in the neuroendocrine response to fasting. Nature 1996;382:250-252.

35 Lord GM, Matarese G, Howard JK, Baker RJ, Bloom SR, Lechler RI: Leptin modulates the t-cell immune response and reverses starvation-induced immunosuppression. Nature 1998;394:897-901.

36 Higami Y, Pugh TD, Page GP, Allison DB, Prolla TA, Weindruch R: Adipose tissue energy metabolism: altered gene expression profile of mice subjected to long-term caloric restriction. FASEB J 2004;18:415-417.

37 Zhu M, Miura J, Lu LX, Bernier M, DeCabo R, Lane MA, Roth GS, Ingram DK: Circulating adiponectin levels increase in rats on caloric restriction: the potential for insulin sensitization. Exp Gerontol 2004;39:1049-1059.

38 Harvie MN, Pegington M, Mattson MP, Frystyk J, Dillon B, Evans G, Cuzick J, Jebb SA, Martin B, Cutler RG, Son TG, Maudsley S, Carlson OD, Egan JM, Flyvbjerg A, Howell A: The effects of intermittent or continuous energy restriction on weight loss and metabolic disease risk markers: a randomized trial in young overweight women. Int J Obes 2011;35:714-727.
39 Imayama I, Ulrich CM, Alfano CM, Wang C, Xiao L, Wener MH, Campbell KL, Duggan C, Foster-Schubert KE, Kong A, Mason CE, Wang CY, Blackburn GL, Bain CE, Thompson HJ, McTiernan A: Effects of a caloric restriction weight loss diet and exercise on inflammatory biomarkers in overweight/obese postmenopausal women: a randomized controlled trial. Cancer Res 2012;72:2314-2326.

40 Jung KJ, Lee EK, Kim JY, Zou Y, Sung B, Heo HS, Kim MK, Lee J, Kim ND, Yu BP, Chung HY: Effect of short term calorie restriction on pro-inflammatory NF-kB and AP-1 in aged rat kidney. Inflamm Res 2009;58:143-150.

41 Kouda K, Iki M: Beneficial effects of mild stress (hormetic effects): dietary restriction and health. J Physiol Anthropol 2010;29:127-132.

42 Scherer T, Buettner C: Yin and Yang of hypothalamic insulin and leptin signaling in regulating white adipose tissue metabolism. Rev Endocr Metab Disord 2011;12:235-243.

43 Piaggi P, Thearle MS, Bogardus C, Krakoff J: Lower energy expenditure predicts long-term increases in weight and fat mass. J Clin Endocrinol Metab 2013;98:E703-E707.

44 Wadden TA, Fujioka K, Toubro S, Gantz I, Erondu NE, Chen M, Suryawanshi S, Carofano W, Johnson-Levonas AO, Shapiro DR, Kaufman KD Heymsfield SB, Amatruda JM: A randomized trial of lifestyle modification and taranabant for maintaining weight loss achieved with a low-calorie diet. Obesity (Silver Spring) 2010;18:2301-2310. 